\title{
Catabolism of 3- and 4-hydroxyphenylacetic acid by Klebsiella pneumoniae
}

\author{
Margarita Martín, ${ }^{1}$ Alicia Gibello, ${ }^{2}$ Javier Fernández, $^{1}$ Estrella Ferrer $^{1}$ and \\ AMANDO GARRIDO-PERTIERRA ${ }^{1 *}$ \\ ${ }^{1}$ Departamento de Bioquimica y Biología Molecular IV, and ${ }^{2}$ Departamento de Microbiología (Patología Animal 1), \\ Facultad de Veterinaria, Universidad Complutense, 28040 Madrid, Spain
}

(Received 30 April 1990; revised 11 October 1990; accepted 23 November 1990)

\begin{abstract}
Klebsiella pneumoniae catabolizes both 4-hydroxyphenylacetic acid and 3-hydroxyphenylacetic acid via metacleavage of 3,4-dihydroxyphenylacetic acid, ultimately yielding pyruvate and succinate. The organism can synthesize two hydroxylases catalysing 3,4-dihydroxyphenylacetic acid formation, which differ in substrate specificity, cofactor requirement, kinetics and regulation. Five enzymes sequentially involved in the catabolism of 3,4-dihydroxyphenylacetic acid are encoded on a $7 \mathrm{kbp}$ fragment of the $K$. pneumoniae chromosome that has been isolated in a recombinant plasmid.
\end{abstract}

\section{Introduction}

The microbial degradation of aromatic compounds is of considerable importance because many herbicides, pesticides and industrial effluents contain a benzene nucleus. Phenylacetic acids are found among a variety of aromatic products formed by anaerobic degradation of phenylalanine and tyrosine (Spoelstra, 1978). In the present work we have studied how Klebsiella pneumoniae metabolizes 3- and 4-hydroxyphenylacetic acid (3- and 4HPA). Two metabolic pathways for the aerobic degradation of 3- and 4-HPA by bacteria have been described. One route involves 3,4-dihydroxyphenylacetic acid (3,4DHPA) (Anderson \& Dagley, 1980; Cooper \& Skinner, $1980 ;$ Sparnins \& Chapman, 1976) and the other involves 2,5-dihydroxyphenylacetate (2,5-DHPA) (Blakey, 1972; van den Tweel et al., 1986, 1988).

Although $K$. pneumoniae is used for many studies in microbial biochemistry, its ability to grow on aromatic compounds has not been shown. We have studied the pathway and regulation of 3- and 4-HPA biodegradation in this micro-organism. We have also undertaken the characterization of two different hydroxylases yielding 3,4-DHPA in $K$. pneumoniae.

Abbreviations: 3-HPA, 3-hydroxyphenylacetic acid; 4-HPA, 4hydroxyphenylacetic acid; 3,4- or 2,5-DHPA, 3,4- or 2,5-dihydroxyphenylacetic acid; CHM, 5-carboxymethyl-2-hydroxymuconate; CHMS, 5-carboxymethyl-2-hydroxymuconate semialdehyde; COHED, 5-carboxymethyl-2-oxo-hex-3-ene-1,6-dioate; HHDD, 2hydroxyhepta-2,4-diene-1,7-dioate; OHED, 2-oxo-hept-3-ene-1,7dioate; SSA, succinic semialdehyde.

\section{Methods}

Bacterial strains, plasmid and growth conditions. Klebsiella pneumoniae strain M5al was obtained from Dr. M. J. Merrlck, AFRC Unit of Nitrogen Fixation, University of Sussex, Brighton, UK; Escherichia coli $5 \mathrm{~K}$ was obtained from Dr R. A. Cooper, Department of Biochemistry, University of Leicester, UK. The plasmid pBR328 was used for cloning the $K$. pneumoniae BamHI DNA fragment. Cells were cultured on medium containing 3-HPA, 4-HPA or 3,4-DHPA (5 mM), glucose $(10 \mathrm{mM})$, succinate $(15 \mathrm{mM})$ or glycerol $(20 \mathrm{mM})$ as carbon source. Medium and growth conditions were as described previously (Sánchez et al., 1989).

Preparation of cell extracts and protein determination. Bacteria from $250 \mathrm{ml}$ medium were harvested in the second half of the exponential growth phase, washed with $50 \mathrm{ml} 0.1 \mathrm{M}$-sodium/potassium phosphate buffer, pH 7.5, containing $1 \mathrm{~mm}$-DTT and $2 \mathrm{~mm}$-EDTA, and their wet weight measured.

To obtain the crude extract, the cells were suspended in two volumes ( $v / w)$ of the above buffer. The cell suspension was disrupted by ultrasonic treatment with a Braun Labsonic sonifier $(70-80 \mathrm{~W})$ at ice temperature for four $30 \mathrm{~s}$ periods, with cooling for $1 \mathrm{~min}$ in between. The suspension was centrifuged at $180000 \mathrm{~g}$ for $90 \mathrm{~min}$ at $4{ }^{\circ} \mathrm{C}$ to remove cell debris and the particulate NADH oxidase activity.

Soluble protein was measured by the method of Bradford (1976), using crystalline bovine serum albumin as standard.

Enzyme assays. All assays were carried out at $30^{\circ} \mathrm{C}$. Spectrophotometric assays were performed with a Pye Unicam PU8800 UV/VIS spectrophotometer. The buffer used in all assays was $0 \cdot 1 \mathrm{M}$-sodium/potassium phosphate buffer, $\mathrm{pH} 7 \cdot 5$. Oxygen consumption experiments were performed with a Gilson Oxygraph model 5/6. The cups contained, in $1.6 \mathrm{ml}$ of $0.1 \mathrm{M}$-sodium/potassium phosphate buffer, $\mathrm{pH}$ $7.0,2 \mathrm{mg}$ (dry weight) of cells and $2 \mu \mathrm{mol}$ substrate.

3-HPA and 4-HPA hydroxylase (EC 1.14.13.-), activities were assayed by measuring $\mathrm{NAD}(\mathrm{P}) \mathrm{H}$ oxidation spectrophotometrically at $340 \mathrm{~nm}$ or oxygen consumption, polarographically. The spectrophoto- 
metric reaction mixture contained, in $1 \mathrm{ml}: 100 \mu \mathrm{mol}$ sodium/potassium phosphate buffer $\mathrm{pH} 7.5,0.26 \mu \mathrm{mol} \mathrm{NAD}(\mathrm{P}) \mathrm{H}$, and bacterial extract (approx. $0.5 \mathrm{mg}$ protein). After measurement of the endogenous oxidation rate, the reaction was started by adding $0.2 \mu \mathrm{mol} 3-\mathrm{HPA}$ or 4HPA. Activity of 3,4-DHPA dioxygenase (EC 1.13.11.15) was measured by the method of Sparnins \& Chapman (1976). CHMS dehydrogenase (EC 1.2.1.-) activity was assayed as described by Alonso \& Garrido-Pertierra (1982). CHM isomerase and COHED decarboxylase (EC 4.1.1.-) were assayed as described by GarridoPertierra \& Cooper (1981). OHED hydratase activity was measured following the method of Ferrer \& Cooper (1988). SSA dehydrogenase (EC 1.2.1 16) activity was assayed as described previously (Sánchez et al., 1989).

Isolation of mutants. Cultures of $K$. pneumoniae strain M5a1 were mutagenized in a minimal salts medium with ethylmethanesulphonate as described by Miller (1972). Survivors were allowed to grow overnight at $30^{\circ} \mathrm{C}$ in $15 \mathrm{~mm}$-succinate minimal medium. Samples of these cultures were then treated with penicillin $\left(1.5 \mathrm{mg} \mathrm{ml}^{-1}\right)$ in the presence of 4HPA and spread onto succinate plates. The colonies obtained were replica-plated onto 4-HPA plates to identify mutants unable to grow on 4-HPA. Such mutants were then tested for their ability to grow on succinate and their inability to grow on 4-HPA. A partially constitutive mutant (relaxed mutant) M5a20 was obtained by the Cohen-Bazire and Jolit method described by Parke \& Ornston (1976).

Preparation of substrates. CHM and CHMS were prepared as described by Sparnins et al. (1974).

Separation of 3- and 4-HPA hydroxylases. The ultracentrifuged extract prepared from about $3 \mathrm{~g}$ of cells (grown in liquid culture on 250 $\mathrm{ml}$ minimal medium plus $5 \mathrm{mM}-3-\mathrm{HPA}$ ) was diluted with $0.1 \mathrm{M}$ sodium/potassium phosphate buffer, $\mathrm{pH} 7.5$, containing $1 \mathrm{~mm}$-DTT and $2 \mathrm{~mm}$-EDTA until a solution of approximately $35 \mathrm{mg}^{2}$ protein $\mathrm{ml}^{-1}$ was obtained. This solution was treated with protamine sulphate (40 $\mathrm{mg} / \mathrm{ml}$ in $0.1 \mathrm{M}$-sodium/potassium phosphate buffer $\mathrm{pH} 7.5$ ) in the proportion $18 \mathrm{mg}$ protamine sulphate to $1 \mathrm{mg}$ bacterial protein. The extract was maintained at $0{ }^{\circ} \mathrm{C}$ with gentle stirring for $15 \mathrm{~min}$ and then centrifuged at $15000 \mathrm{~g}$ for $15 \mathrm{~min}$ at $4^{\circ} \mathrm{C}$ to remove the precipitate. The supernatant was applied to a Superose 6 column and chromatographed using a Pharmacia fast protein liquid chromatography (FPLC) system. The column was eluted with $0.1 \mathrm{M}$-sodium/potassium phosphate buffer, $\mathrm{pH} 7.5$, at a flow rate of $0.5 \mathrm{ml} \mathrm{min}{ }^{-1}$, collecting $1.0 \mathrm{ml}$ fractions. Details of the separation of the two hydroxylases are given in Table 3 and Fig. 2.

A similar procedure to that described above was carried out with cells grown in 4-HPA to partially purify the 4-HPA hydroxylase.

Molecular mass determination. Native protein molecular masses were estimated by FPLC using a Pharmacia Superose 6 HR 10/30 gel filtration column. Samples were run in $0.1 \mathrm{M}$-sodium/potassium phosphate buffer, $\mathrm{pH} 7.5$, at a flow rate of $0.5 \mathrm{ml} \mathrm{min}^{-1}$. The column was calibrated using thyroglobulin (669 kDa); ferritin (440 kDa); catalase $(232 \mathrm{kDa})$; lactate dehydrogenase $(140 \mathrm{kDa})$ and bovine serum albumin $(67 \mathrm{kDa})$.

DNA manipulations. Chromosomal $K$. pneumoniae DNA was isolated by the method of Chow et al. (1977). DNA was digested with BamHI under conditions recommended by the supplier. Transformations were carried out by the freeze-thaw procedure described by Merrick et al. (1987). Oligonucleotides were synthesized with a Pharmacia DNA synthesizer based on part of the N-terminal amino acid sequence of $K$. pneumoniae CHMS dehydrogenase (Fawcett et al., 1989). The mixture of oligonucleotides was generated by mixed base addition. Oligonucleotides were labelled with $\left[\gamma^{-32} \mathrm{P}\right] \mathrm{ATP}$ according to the procedure of Maniatis et al (1982). Hybridization was performed for $16 \mathrm{~h}$ at $30^{\circ} \mathrm{C}$ by standard procedures (Maniatis et al., 1982).
Chemicals. 3-HPA, 4-HPA and 3,4-DHPA were from Sigma. Chromatographic material was purchased from Pharmacia. NADH, NADPH, FAD and restriction endonucleases were from Boehringer. All the other compounds were of the highest purity available.

\section{Results}

\section{Oxidative abilities of whole cells}

Washed cell suspensions of $K$. pneumoniae M5al grown on 3- or 4-HPA as sole carbon source were able to oxidize 3-HPA, 4-HPA and 3,4-DHPA rapidly (Table 1); however, they were not capable of oxidizing 2,5-DHPA. Cell suspensions grown on succinate or glycerol failed to oxidize 3-HPA, 4-HPA and 3,4-DHPA. These observations suggested that both 3-and 4-HPA were catabolized by the 3,4-DHPA pathway (Fig. 1) rather than by the 2,5DHPA pathway.

\section{Activities of the 3- and 4-HPA catabolic enzymes}

Extracts prepared from cells grown on 4-HPA possessed the enzymes required to catabolize 3- and 4-HPA via 3,4DHPA, to succinic semialdehyde (SSA) and pyruvate (Table 2). These extracts showed hydroxylase activity only with $\mathrm{NADH}$ as cosubstrate. However, extracts prepared from cells grown on 3-HPA showed 4-HPA hydroxylase activity using only NADH as cofactor and 3-HPA hydroxylase activity using either NADH or NADPH as cofactor. These data suggested that two distinct enzymes were involved in the hydroxylation reactions. When cells were grown on 3,4-DHPA, neither 3-HPA nor 4-HPA hydroxylase activity could be detected but 3,4-DHPA was able to induce (directly or indirectly) all the subsequent enzymes involved in the pathway. No activity of the enzymes involved in the degradation of 3 -and 4-HPA was found when cells were grown on glycerol or succinate, indicating that these enzymes are inducible.

Table 1. Rates of oxidation by washed cells of $K$. pneumoniae MSal

The results are means of four determinations \pm SD.

\begin{tabular}{|c|c|c|c|c|c|}
\hline \multirow{3}{*}{$\begin{array}{l}\text { Growth } \\
\text { substrate }\end{array}$} & \multicolumn{5}{|c|}{$Q_{\mathrm{O}_{2}}\left[\mathrm{nmol} \mathrm{O}_{2}\right.$ consumed $\left.\mathrm{min}^{-1}(\mathrm{mg} \text { dry wt of cells })^{-1}\right]$} \\
\hline & \multicolumn{5}{|c|}{ Oxidation substrate } \\
\hline & 3-HPA & 4-HPA & 3,4-DHPA & 2,5-DHPA & 2-HPA \\
\hline Glycerol & $<1$ & $<1$ & $<1$ & $<1$ & $<1$ \\
\hline Succinate & $<1$ & $<1$ & $<1$ & $<1$ & $<1$ \\
\hline 3-HPA & $120 \pm 18$ & $130 \pm 21$ & $130 \pm 9$ & $<1$ & $<1$ \\
\hline 4-HPA & $98 \pm 12$ & $140 \pm 16$ & $179 \pm 18$ & $<1$ & $<1$ \\
\hline 3,4-DHPA & $<1$ & $<1$ & $150 \pm 17$ & $<1$ & $<1$ \\
\hline
\end{tabular}




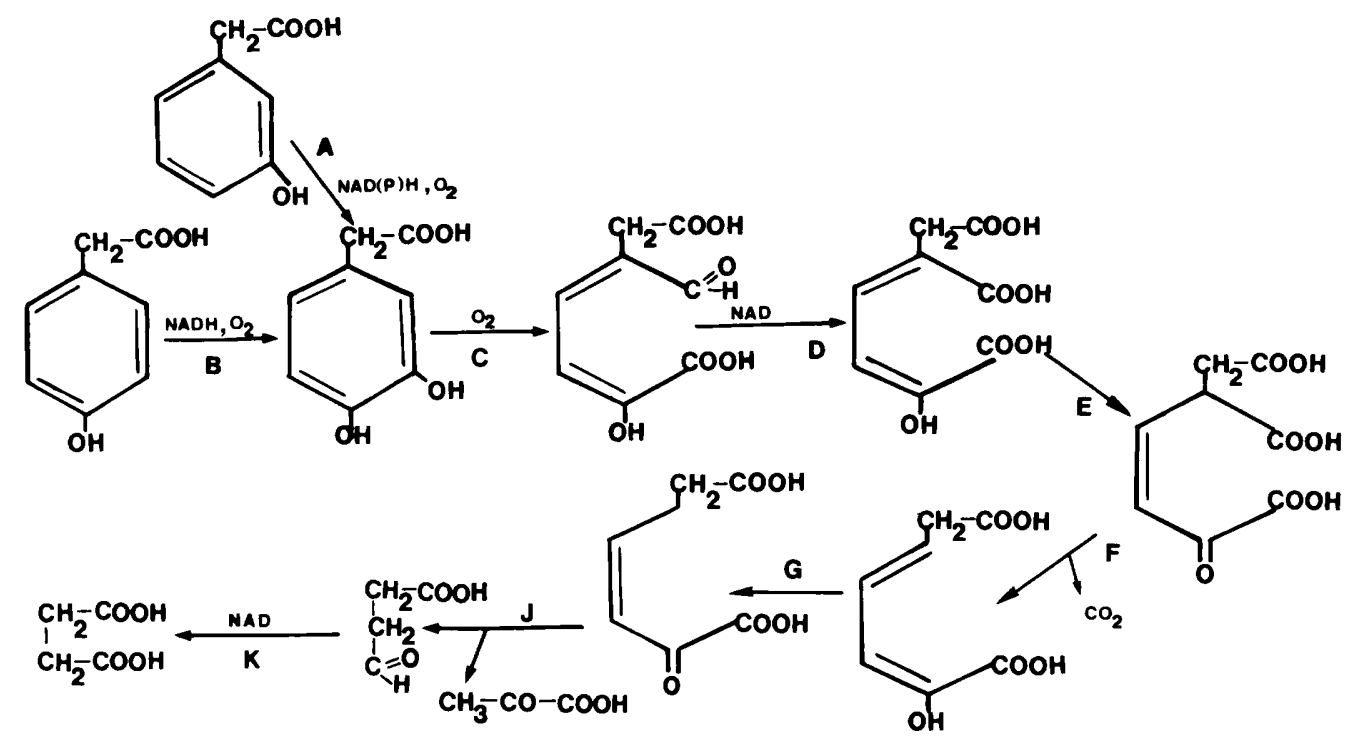

Fig. 1. Pathways of degradation of 3- and 4-HPA. Enzymes are as follows: A, 3-hydroxyphenylacetate (3-HPA) hydroxylase; B, 4hydroxyphenylacetate (4-HPA) hydroxylase; C, 3,4-dihydroxyphenylacetate (3,4-DHPA) dioxygenase; D, 5-carboxymethyl-2hydroxymuconate (CHM) semialdehyde dehydrogenase; E, CHM isomerase; F, 5-carboxymethyl-2-oxo-hex-3-ene-1,6-dioate (COHED) decarboxylase; G, 2-hydroxyhepta-2,4-diene-1,7-dioate (HHDD) isomerase; J, 2-oxo-hept-3-ene-1,7-dioate (OHED) hydratase; K, succinic semialdehyde (SSA) dehydrogenase

Table 2. Activities of the 3-and 4-HPA catabolic enzymes induced by growth on different compounds in K. pneumoniae M5al

\begin{tabular}{|c|c|c|c|c|c|c|c|c|}
\hline \multirow[b]{3}{*}{ Growth substrate } & \multicolumn{8}{|c|}{ Specific activity $\left[\mathrm{nmol}\right.$ substrate transformed $\left.\min ^{-1}(\mathrm{mg} \text { protein })^{-1}\right]$} \\
\hline & \multicolumn{2}{|c|}{$\begin{array}{c}\text { 3-HPA } \\
\text { hydroxylase }\end{array}$} & \multirow{2}{*}{$\begin{array}{c}\text { 4-HPA } \\
\text { hydroxylase } \\
\text { NADH }\end{array}$} & \multirow{2}{*}{$\begin{array}{c}\text { 3,4-DHPA } \\
\text { dioxygenase }\end{array}$} & \multirow{2}{*}{$\begin{array}{c}\text { CHMS } \\
\text { dehydrogenase }\end{array}$} & \multirow{2}{*}{$\begin{array}{c}\text { CHM } \\
\text { isomerase }\end{array}$} & \multicolumn{2}{|c|}{$\begin{array}{c}\text { SSA } \\
\text { dehydrogenase }\end{array}$} \\
\hline & NADH & NADPH & & & & & NAD & NADP \\
\hline 3-HPA & $32 \pm 10$ & $18 \pm 5$ & $38 \pm 10$ & $170 \pm 20$ & $70 \pm 10$ & $120 \pm 6$ & $240 \pm 5$ & $87 \pm 5$ \\
\hline 4-HPA & - & - & $45 \pm 18$ & $180 \pm 10$ & $74 \pm 5$ & $128 \pm 7$ & $245 \pm 2$ & $90 \pm 2$ \\
\hline 3,4-DHPA & - & - & - & $180 \pm 9$ & $80 \pm 6$ & $140 \pm 9$ & $210 \pm 10$ & $92 \pm 5$ \\
\hline Glycerol & - & - & - & - & - & - & - & $60 \pm 10$ \\
\hline Succinate & - & - & - & - & - & - & - & $64 \pm 5$ \\
\hline Glucose + 3-HPA & - & - & - & - & - & - & - & $60 \pm 6$ \\
\hline Glucose + 3-HPA + cAMP & $22 \pm 3$ & $15 \pm 5$ & $30 \pm 6$ & $160 \pm 3$ & $64 \pm 6$ & $130 \pm 7$ & $235 \pm 9$ & $100 \pm 8$ \\
\hline 3-HPA + cAMP & $50 \pm 7$ & $30 \pm 6$ & $70 \pm 6$ & $250 \pm 10$ & $120 \pm 9$ & $230 \pm 7$ & $320 \pm 8$ & ND \\
\hline
\end{tabular}

ND, Not determined.

* Values are expressed as the mean of four determinations \pm SD.

\section{Characterization of 3- and 4-HPA hydroxylase activities}

3- and 4-HPA hydroxylase activities were separated from protamine sulphate treated extracts of cells grown on 3HPA by gel filtration chromatography (Table $3 a$, Fig. 2a). From a Superose column, an hydroxylase activity was found with 3-HPA and NADH or NADPH in fractions 35,36 and 37 . No activity with 4-HPA was observed in these fractions. However, fractions 39 to 42 showed hydroxylase activity with 3- and 4-HPA, using only NADH as cofactor. Neither activity was detected in fraction 38 (Fig. $2 a$ ). The enzyme that only recognizes 3-
HPA as substrate was called 3-HPA hydroxylase. The enzyme that only recognizes NADH as cosubstrate was designated 4-HPA hydroxylase. The 3-HPA hydroxylase eluted before the 4-HPA hydroxylase (Fig. 2a), corresponding to apparent molecular masses of $385 \pm 10$ and $335 \pm 10 \mathrm{kDa}$ respectively. When cells were grown on 4HPA, no activity of the 3-HPA hydroxylase was found (Table $3 b$ ). However, extracts from these cells showed a 4-HPA hydroxylase activity that eluted from a Superose column in the same fractions as those from cells grown on 3-HPA (Fig. 2b).

The most active fractions were employed for a series of 
Table 3. Summary of the separation of 3-HPA and 4-HPA hydroxylase activities from K. pneumoniae M5al

\begin{tabular}{|c|c|c|c|c|c|c|c|c|c|}
\hline & \multirow[b]{2}{*}{$\begin{array}{l}\text { Volume } \\
\text { (ml) }\end{array}$} & \multirow[b]{2}{*}{$\begin{array}{l}\text { Protein } \\
\text { (mg) }\end{array}$} & \multicolumn{3}{|c|}{ Hydroxylase activity $\ddagger$} & \multicolumn{3}{|c|}{ Specific activity $\ddagger$} & \multirow[b]{2}{*}{$\begin{array}{l}\text { Yield } \\
(\%)\end{array}$} \\
\hline & & & $\begin{array}{l}\text { 3-HPA } \\
\text { NADPH }\end{array}$ & $\begin{array}{l}\text { 3-HPA } \\
\text { NADH }\end{array}$ & $\begin{array}{l}\text { 4-HPA } \\
\text { NADH }\end{array}$ & $\begin{array}{l}\text { 3-HPA } \\
\text { NADPH }\end{array}$ & $\begin{array}{l}\text { 3-HPA } \\
\text { NADH }\end{array}$ & $\begin{array}{l}\text { 4-HPA } \\
\text { NADH }\end{array}$ & \\
\hline \multicolumn{10}{|l|}{ (a) Cells grown on 3-HPA } \\
\hline $\begin{array}{l}\text { Supernatants of } \\
\text { ultracentrifuged extract }\end{array}$ & 4 & 36 & 1008 & 1240 & 1990 & 28 & $34 \cdot 5$ & $55 \cdot 5$ & - \\
\hline $\begin{array}{l}\text { Protamine sulphate } \\
\text { Superose } 6\end{array}$ & $4 \cdot 5$ & 20 & 940 & 1180 & 1860 & 47 & 59 & 93 & 94 \\
\hline Fractions $35-37$ & 3 & 1.6 & 494 & 557 & $<1$ & 308 & 360 & $<1$ & 48 \\
\hline Fractions $39-42$ & 3 & $2 \cdot 5$ & $<1$ & 900 & 1230 & $<1$ & 360 & 492 & $72 \S$ \\
\hline \multicolumn{10}{|l|}{ (b) Cells grown on 4-HPA } \\
\hline $\begin{array}{l}\text { Supernatant of } \\
\text { ultracentrifuged extract }\end{array}$ & 4 & 40 & $\cdot<1$ & 1360 & 1680 & $<1$ & 34 & 42 & - \\
\hline $\begin{array}{l}\text { Protamine sulphate } \\
\text { Superose } 6\end{array}$ & $4 \cdot 5$ & 27 & $<1$ & 1320 & 1600 & $<1$ & 49 & 59 & 96 \\
\hline Fractions $35-37$ & 3 & 2 & $<1$ & $<1$ & $<1$ & $<1$ & $<1$ & $<1$ & - \\
\hline Fractions $39-42$ & 3 & 3 & $<1$ & 1050 & 1240 & $<1$ & 350 & 413 & 74 \\
\hline
\end{tabular}

* Expressed in nmol substrate transformed $\min ^{-1}$.

$\dagger$ Expressed in nmol substrate transformed min $^{-1}$ (mg protein) ${ }^{-1}$.

$\ddagger$ Substrates and coenzymes used in the enzymic activity determinations are indicated above the respective columns. $\S$ As determined with 3-HPA and NADH.
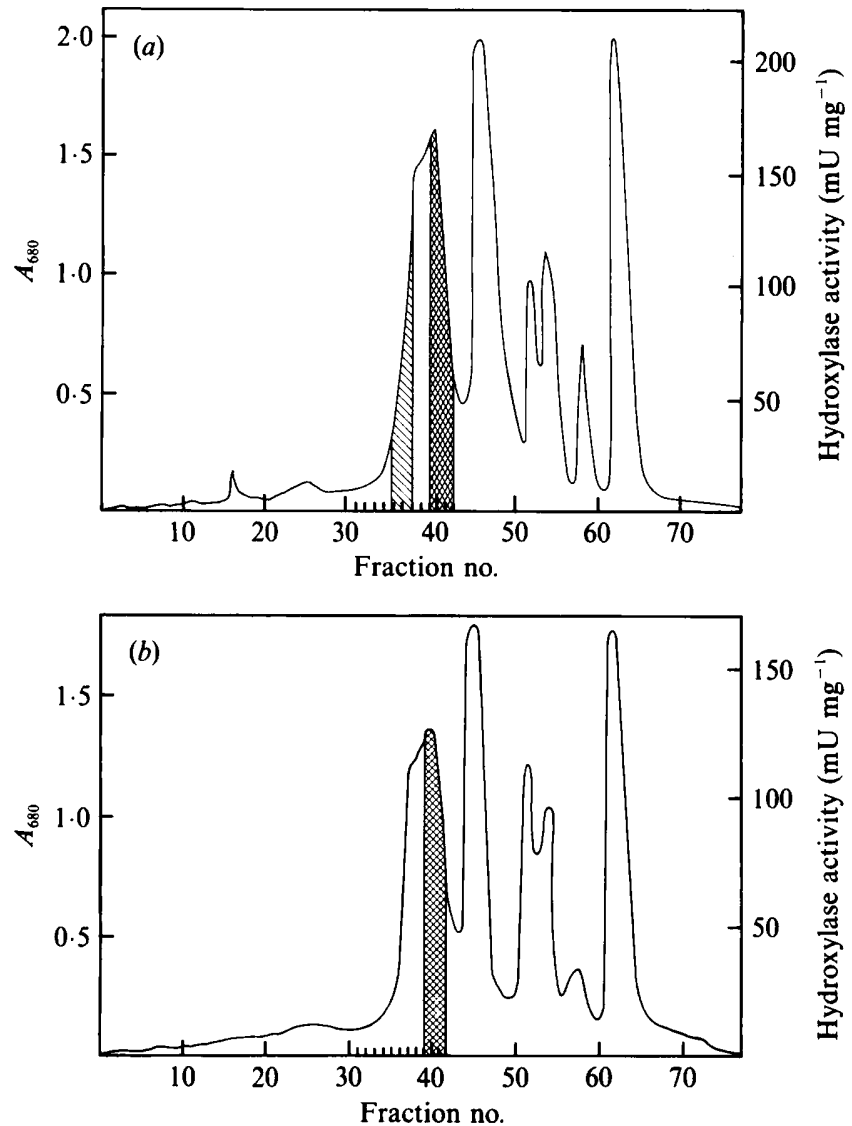

Fig. 2. (a) Profile of elution from a Superose 6 column of extract from cells grown on 3-HPA. $\mathbb{\text { , }}$ 3-HPA hydroxylase activity (with NADPH as cofactor); 4-HPA hydroxylase activity (with 4-HPA as substrate). (b) Profile of elution from a Superose 6 column of extract (from cells grown on 4-HPA. 4-HPA hydroxylase activity (with 4HPA as substrate). kinetic studies. 3-HPA hydroxylase showed sigmoidal kinetics when 3-HPA was the variable substrate in the presence of $150 \mu \mathrm{M}-\mathrm{NADH}$ or $150 \mu \mathrm{M}-\mathrm{NADPH}$. The saturation curves were indicative of positive cooperativity. However, 4-HPA hydroxylase showed hyperbolic kinetics when 3-HPA or 4-HPA was the variable substrate in the presence of $150 \mu \mathrm{M}-\mathrm{NADH}$. This latter enzyme showed sigmoidal kinetics only when NADH was the variable substrate in the presence of $2000 \mu \mathrm{M}-4-$ HPA.

Values of the kinetic parameters were obtained from the slopes and intercepts of reaction rates against $1 /[\mathrm{NADH}]$ or $1 /[\mathrm{NADPH}]$ and $1 /[3-\mathrm{HPA}], 1 /[\mathrm{NADPH}]$ and 1/[4-HPA]. Straight lines were obtained in all cases and from these it was possible to calculate $V$ and apparent $K_{\mathrm{m}}$ values (Table 4). The 4-HPA hydroxylase isolated from cells grown on 4-HPA showed the same kinetic behaviour, with similar kinetic parameter values, as that from cells grown on 3-HPA. Both hydroxylase activities were stimulated by the addition of $2 \mu \mathrm{M}-\mathrm{FAD}$, and both enzymes were very unstable, their activity decreasing to undetectable levels in less than $48 \mathrm{~h}$ at $30^{\circ} \mathrm{C}$.

\section{Isolation and characterization of mutants}

4-HPA-negative mutants of $K$. pneumoniae were isolated. They could be identified by their growth phenotypes on agar plates. Approximately 500 colonies were tested and 65 of them showed a 4-HPA negative phenotype. Two mutants grew on 3,4-DHPA but not on 4-HPA; they were presumed to be affected in 4-HPA uptake or 4-HPA hydroxylase and were named M5a12. Three mutants 
Table 4. Apparent kinetic parameters of the partially purified* 3-HPA and 4-HPA hydroxylase of K. pneumoniae M5al

\begin{tabular}{|c|c|c|c|c|c|c|c|}
\hline $\begin{array}{l}\text { Growth } \\
\text { substrate }\end{array}$ & Enzyme & $\begin{array}{c}\text { Substrate } \\
\text { (variable concn) } \\
(\mu \mathrm{M})\end{array}$ & $\begin{array}{c}\text { Substrate } \\
\text { (constant concn) } \\
(\mu \mathrm{M})\end{array}$ & $\begin{array}{c}K_{\mathrm{m}} \\
(\mu \mathrm{M})\end{array}$ & $\begin{array}{c}V \\
\text { (nmol substrate } \\
\text { transformed } \min ^{-1} \mathrm{mg}^{-1} \text { ) }\end{array}$ & $\begin{array}{l}S_{0 \cdot 5} \\
(\mu \mathrm{M})\end{array}$ & $\begin{array}{c}\text { Hill } \\
\text { coefficient }\end{array}$ \\
\hline \multirow[t]{4}{*}{ 3-HPA } & $\begin{array}{l}\text { 3-HPA } \\
\text { hydroxylase }\end{array}$ & $\begin{array}{r}3-\mathrm{HPA} \\
30-3000\end{array}$ & $\begin{array}{l}\text { NADH } \\
150\end{array}$ & - & $21 \cdot 5$ & 160 & 2.05 \\
\hline & & $\begin{array}{r}3-\mathrm{HPA} \\
30-3000\end{array}$ & $\begin{array}{l}\text { NADPH } \\
150\end{array}$ & & $18 \cdot 0$ & 190 & 2.05 \\
\hline & & $\begin{array}{l}\text { NADH } \\
12-350\end{array}$ & $\begin{array}{l}3-\mathrm{HPA} \\
2000\end{array}$ & 43 & 34 & & \\
\hline & & $\begin{array}{l}\text { NADPH } \\
12-350\end{array}$ & $\begin{array}{l}\text { 3-HPA } \\
2000\end{array}$ & 100 & 23 & & \\
\hline \multirow[t]{4}{*}{$\begin{array}{l}\text { 3-HPA } \\
\text { (or 4-HPA) }\end{array}$} & $\begin{array}{l}\text { 4-HPA } \\
\text { hydroxylase }\end{array}$ & $\begin{array}{r}\text { 4-HPA } \\
30-3000\end{array}$ & $\begin{array}{l}\text { NADH } \\
150\end{array}$ & 127 & 66 & & \\
\hline & & $\begin{array}{r}3-\mathrm{HPA} \\
30-3000\end{array}$ & $\begin{array}{l}\text { NADH } \\
150\end{array}$ & 225 & 58 & & \\
\hline & & $\begin{array}{c}\text { NADH } \\
12-360\end{array}$ & $\begin{array}{l}\text { 4-HPA } \\
2000\end{array}$ & & 42 & 45 & $2 \cdot 6$ \\
\hline & & $\begin{array}{c}\text { NADH } \\
12-360\end{array}$ & $\begin{array}{l}3-\mathrm{HPA} \\
2000\end{array}$ & 80 & 73 & & \\
\hline
\end{tabular}

* Extracts lost activity completely in less than $48 \mathrm{~h}$, so that the purity of samples fractionated as described in Table 3 was unverifiable.

accumulated a brown colour after growing on glycerol/4HPA plates; they were presumably 3,4-DHPA dioxygenase mutants and were named M5a13. Another four mutants accumulated a yellow colour on glycerol/4-HPA plates; they were presumed to be CHMS-dehydrogenase mutants and were named M5a14. The rest of the mutants tested accumulated no colour when they were grown on glycerol/4-HPA plates and they showed very low activities of all the 4-HPA catabolic enzymes; they were probably pleiotropic mutants. When mutants of the first class (M5a12) were grown in liquid medium containing glycerol plus 3,4-DHPA, the activities for the 3,4-DHPA dioxygenase and subsequent enzymes were similar to those found in the wild-type strain grown under the same conditions (Table 5). Grown in the presence of 4-HPA, M5a12, unlike the wild-type, lacked activities of all enzymes of the 4-HPA catabolic pathway. It appears that 4-HPA induces only the hydroxylase and is unable to directly induce any of the other enzymes of 4-HPA catabolism. Extracts of M5a13 cells grown on glycerol plus 4-HPA showed no 3,4-DHPA dioxygenase NADdependent or SSA dehydrogenase activities, and approximately $80 \%$ of the activities of other enzymes of the pathway when compared with the wild-type (Table 5). Apparently, sequential induction occurs, with 4-HPA normally being transformed into 3,4-DHPA, which acts as the inducer of the subsequent enzymes of the pathway. When mutant M5a14 (Table 5) was grown in liquid culture on glycerol, in the presence of 4-HPA, a yellow compound accumulated in the medium which had similar spectral characteristics to those described for CHMS (Sparnins \& Chapman, 1976); the extracts of these mutants contained no CHMS dehydrogenase or NAD-dependent SSA dehydrogenase, but showed similar levels of activity for the rest of the enzymes as those found in the induced wild-type. The low activity of NAD-linked SSA dehydrogenase found in extracts of these mutants confirmed that this enzyme is induced only by its substrate (SSA), as we reported previously (Sánchez et al., 1989). We isolated another type of mutant, M5a20 (Rex) (Table 5), which had a partially constitutive phenotype for 3,4-DHPA utilization.

\section{Construction of a labelled oligonucleotide probe}

The first $20 \mathrm{~N}$-terminal amino acid residues of the $K$. pneumoniae CHMS dehydrogenase were published previously (Fawcett et al., 1989). All possible codons corresponding to the amino acid residues 1-6 were used to specify a degenerate oligonucleotide DNA probe (Fig. 3).

\section{Isolation of cloned hpa genes}

Chromosomal DNA from $K$. pneumoniae M5al was partially digested with the restriction enzyme BamHI to give fragments of approximately $10 \mathrm{kbp}$ and ligated into BamHI-digested plasmid vector pBR328. The ligation mixture was used to transform $E$. coli $5 \mathrm{~K}$, a strain of $E$. coli K 12 which lacks the hpa genes (Fawcett et al., 1989), and ampicillin-resistant transformants were selected on Luria broth plates plus ampicillin. Fifteen hundred transformant colonies were blotted onto nitrocellulose 
Table 5. Activities of the 4-HPA catabolic enzymes in crude extracts from mutants of $K$. pneumoniae M5aI

\begin{tabular}{|c|c|c|c|c|c|c|c|c|}
\hline \multirow[b]{3}{*}{ Strain (phenotype) } & \multirow{3}{*}{$\begin{array}{l}\text { Growth } \\
\text { substrate* }\end{array}$} & \multicolumn{7}{|c|}{ Specific activity $\nmid$ [nmol substrate transformed $\min ^{-1}(\text { mg protein })^{-1}$ ] } \\
\hline & & \multicolumn{2}{|c|}{$\begin{array}{c}\text { 4-HPA } \\
\text { hydroxylase }\end{array}$} & \multirow{2}{*}{$\begin{array}{c}\text { 3,4-DHPA } \\
\text { dioxygenase }\end{array}$} & \multirow{2}{*}{$\begin{array}{c}\text { CHMS } \\
\text { dehydrogenase }\end{array}$} & \multirow{2}{*}{$\begin{array}{c}\text { CHM } \\
\text { isomerase }\end{array}$} & \multicolumn{2}{|c|}{$\begin{array}{c}\text { SSA } \\
\text { dehydrogenase }\end{array}$} \\
\hline & & 4-HPA & 3-HPA & & & & NAD & NADP \\
\hline $\begin{array}{l}\text { M5al (wild-type) } \\
\text { M5a1 (wild-type) }\end{array}$ & $\begin{array}{l}\text { 4-HPA } \\
\text { 3,4-DHPA }\end{array}$ & $\begin{array}{r}34 \pm 6 \\
<1\end{array}$ & $\begin{array}{r}26 \pm 9 \\
<1\end{array}$ & $\begin{array}{l}170 \pm 12 \\
230 \pm 26\end{array}$ & $\begin{array}{l}70 \pm 10 \\
80 \pm 10\end{array}$ & $\begin{array}{l}120 \pm 6 \\
125 \pm 7\end{array}$ & $\begin{array}{l}350 \\
420\end{array}$ & $\begin{array}{l}40 \\
38\end{array}$ \\
\hline $\begin{array}{l}\text { M5a12 }\left(\mathrm{Hpa}^{-}\right) \\
\text {M5a12 }\left(\mathrm{Hpa}^{-}\right)\end{array}$ & $\begin{array}{l}\text { Glyc. + 3,4-DHPA } \\
\text { Glyc. + 4-HPA }\end{array}$ & $\begin{array}{l}<1 \\
<1\end{array}$ & $\begin{array}{l}<1 \\
<1\end{array}$ & $\underset{<1}{210 \pm 15}$ & $\begin{array}{r}80 \pm 12 \\
5 \pm 10\end{array}$ & $\begin{array}{r}120 \pm 6 \\
6 \pm 1\end{array}$ & $\begin{array}{r}390 \\
3\end{array}$ & $\begin{array}{l}30 \\
\text { ND }\end{array}$ \\
\hline M5a13 $\left(\mathrm{HpaB}^{-}\right)$ & Glyc. + 4-HPA & $10 \pm 2$ & $18 \pm 4$ & 2 & $50 \pm 6$ & $110 \pm 7$ & 3 & ND \\
\hline M5a14 (HpaC-) & Glyc. + 4-HPA & $20 \pm 6$ & $26 \pm 5$ & $230 \pm 18$ & $<1$ & $140 \pm 11$ & $<1$ & ND \\
\hline $\begin{array}{l}\text { M5a20 (Rex) } \\
\text { M5a20 (Rex) } \\
\text { M5a20 (Rex) } \\
\text { M5a20 (Rex) }\end{array}$ & $\begin{array}{l}\text { Glyc. } \\
\text { Glyc. + 4-HPA } \\
\text { Glucose } \\
\text { Glyc. + 4-HPA + cAMP }\end{array}$ & $\begin{array}{r}<1 \\
22 \pm 6 \\
<1 \\
28 \pm 9\end{array}$ & $\begin{array}{r}<1 \\
26 \pm 6 \\
<1 \\
30 \pm 6\end{array}$ & $\begin{array}{l}190 \pm 18 \\
160 \pm 12 \\
18 \pm 2 \\
210 \pm 16\end{array}$ & $\begin{array}{l}70 \pm 9 \\
80 \pm 6 \\
10 \pm 1 \\
74 \pm 5\end{array}$ & $\begin{array}{r}120 \pm 6 \\
130 \pm 9 \\
14 \pm 1 \\
125 \pm 6\end{array}$ & $\begin{array}{l}<1 \\
410 \\
<1 \\
250\end{array}$ & $\begin{array}{l}\text { ND } \\
32 \\
28 \\
90\end{array}$ \\
\hline
\end{tabular}

\begin{tabular}{|c|c|c|c|c|c|}
\hline Residue number ... & 1 & 2 & 3 & 4 & 5 \\
\hline $\begin{array}{l}\text { Amino acid } \\
\text { sequence } \ldots\end{array}$ & Met & Lys & Lys & Ile & Asn \\
\hline $\begin{array}{l}\text { Oligonucleotide } \\
\text { sequence ... }\end{array}$ & AUG & $\begin{array}{r}\text { AAA } \\
G\end{array}$ & $\begin{array}{r}\text { AAA } \\
G\end{array}$ & $\begin{array}{r}\text { AUU } \\
\mathrm{C} \\
\mathrm{A}\end{array}$ & $\begin{array}{r}A \cup U \\
C\end{array}$ \\
\hline
\end{tabular}

Fig. 3. Sequence of the degenerate oligonucleotide probe corresponding to N-terminal residues $1-6$ of $K$. pneumoniae M5al CHMS dehydrogenase.

filters and hybridized with the ${ }^{32} \mathrm{P}$-labelled degenerate oligonucleotide probe. When the nitrocellulose filters were autoradiographed, one colony showed strong hybridization. The plasmid carried by this transformant contained a $7 \mathrm{kbp}$ insert of DNA and was designated pJF001.

\section{Properties of pJF001}

As shown in Table 2, the enzymes of the 4-HPA catabolic pathway were not present in glycerol-grown cells of $K$. pneumoniae M5al but were induced when 4-HPA was included or used as the sole carbon source. $E$. coli $5 \mathrm{~K}$ (pJF001) was unable to grow on 4-HPA or 3,4DHPA, but extracts from cells grown on glycerol minimal medium plus ampicillin or Luria broth plus ampicillin showed activities of 3,4-DHPA dioxygenase, CHMS dehydrogenase, CHM isomerase, COHED decarboxylase and OHED hydratase (Table 6). This indicated that the genes coding for these enzymes had been cloned and that their expression was unregulated in E. coli $5 \mathrm{~K}$. When pJF001 was introduced by transforma- tion into the $K$. pneumoniae CHMS dehydrogenase mutant M5a14, the ability to grow on 4-HPA as sole carbon source was restored. Plasmid DNA was isolated from the transformant and was identified by digestion with restriction enzymes (BamHI, Pst I and EcoRI) as the pJF001 used for transformation. Table 6 shows the activities of the 3,4-DHPA catabolic enzymes detected in M5a14(pJF001) when grown on 4-HPA. The activities observed were similar to those of the wild-type grown on the same substrates.

Effect of cAMP on the catabolic enzymes of the 4-HPA pathway

The presence of 2 mM-cAMP increased enzyme activities in bacteria grown on 4-HPA about twofold and overcame the repression of enzyme synthesis produced by glucose (Table 2). This effect is generally interpreted as resulting from a more efficient initiation of transcription mediated by cAMP-CAP (Postma, 1986). No significant differences in the enzyme activities corresponding to the genes encoded in pJF001 were found when $E$. coli $5 \mathrm{~K}$ harbouring the plasmid was grown on glycerol plus 3,4-DHPA (Table 6) and in the presence of glucose and/or cAMP (data not shown).

\section{Discussion}

The regulation of the biodegradative pathway of 3- and 4-HPA in $K$. pneumoniae has not previously been investigated. The results presented here show that in $K$. pneumoniae M5al both compounds are catabolized by a 
Table 6. Activities of the 4-HPA catabolic enzymes in E. coli $5 K(p J F 001)$

\begin{tabular}{|c|c|c|c|c|c|c|c|}
\hline \multirow[b]{2}{*}{ Strain } & \multirow[b]{2}{*}{$\begin{array}{l}\text { Growth } \\
\text { substrate* }\end{array}$} & \multicolumn{6}{|c|}{ Specific activity† [nmol substrate transformed $\left.\min ^{-1}(\mathrm{mg} \text { protein })^{-1}\right]$} \\
\hline & & $\begin{array}{c}\text { 4-HPA } \\
\text { hydroxylase }\end{array}$ & $\begin{array}{c}\text { 3,4-DHPA } \\
\text { dioxygenase }\end{array}$ & $\begin{array}{c}\text { CHMS } \\
\text { dehydrogenase }\end{array}$ & $\begin{array}{l}\text { CHM } \\
\text { isomerase }\end{array}$ & $\begin{array}{c}\text { COHED } \\
\text { decarboxylase }\end{array}$ & $\begin{array}{c}\text { OHED } \\
\text { hydratase }\end{array}$ \\
\hline K. pneumoniae M5a1 & 4-HPA & $38 \pm 8$ & $170 \pm 16$ & $150 \pm 6$ & $88 \pm 10$ & $180 \pm 10$ & $42 \pm 4$ \\
\hline E. coli $5 \mathrm{~K}$ & Glyc. + 4-HPA & $<1$ & $<1$ & $<1$ & $<1$ & $<1$ & $<1$ \\
\hline E. coli $5 \mathrm{~K}(\mathrm{pJF} 001)$ & $\begin{array}{l}\text { Glyc. + 4-HPA } \\
\text { Glyc. } \\
\text { LB } \\
\text { Glyc. + 3,4-DHPA }\end{array}$ & $\begin{array}{l}<1 \\
<1 \\
<1 \\
<1\end{array}$ & $\begin{array}{l}210 \pm 20 \\
170 \pm 18 \\
150 \pm 8 \\
200 \pm 17\end{array}$ & $\begin{array}{l}120 \pm 2 \\
110 \pm 10 \\
120 \pm 2 \\
130 \pm 5\end{array}$ & $\begin{array}{r}120 \pm 7 \\
130 \pm 9 \\
90 \pm 6 \\
120 \pm 7\end{array}$ & $\begin{array}{l}150 \pm 9 \\
135 \pm 9 \\
130 \pm 7 \\
150 \pm 9\end{array}$ & $\begin{array}{l}50 \pm 6 \\
46 \pm 3 \\
45 \pm 2 \\
55 \pm 7\end{array}$ \\
\hline $\begin{array}{l}\text { K. pneumoniae } \\
\text { M5a14(pJF001) }\end{array}$ & 4-HPA & $28 \pm 5$ & $250 \pm 22$ & $130 \pm 5$ & $180 \pm 2$ & $200 \pm 16$ & $52 \pm 9$ \\
\hline
\end{tabular}

* Glyc., glycerol; LB, Luria broth.

$\dagger$ Values are expresed as the mean of four determinations \pm SD.

meta-cleavage pathway, with 3,4-DHPA as the ring fission intermediate. No other bacterium has been shown to employ this mechanism of 3-HPA catabolism (Adachi et al., 1964; Sparnins et al., 1974, 1978). Of particular significance is the presence of two distinct hydroxylases in extracts of $K$. pneumoniae M5a1. 3-HPA hydroxylase is only induced by 3-HPA, only recognizes 3HPA as substrate and can use either NADH or NADPH as cofactor. 4-HPA hydroxylase is induced by either 3HPA or 4-HPA, recognizes either compound as substrate and uses only NADH as cofactor. The two enzymes differ in molecular mass and in their kinetic behaviour and kinetic parameters. It is likely that the two enzymes are different proteins, each specified by a distinct gene. This is in contrast to a single hydroxylase for both compounds as was suggested for E. coli (Cooper \& Skinner, 1980).

Two different differentially induced hydroxylases have already been suggested for 3- and 4-HPA catabolism via 2,5-DHPA by Flavobacterium sp. (van den Tweel et al., 1988), but the existence of two hydroxylases involved in the metabolism of these two compounds via 3,4-DHPA has not been reported before.

Our data suggest that this pathway is regulated as four distinguishable units. The 4-HPA and 3-HPA hydroxylases are not induced in the same way. The majority of the other enzymes are induced by 3,4-DHPA. Lastly, the (apparently pathway-specific) SSA dehydrogenase is independently regulated. Consistent with this pattern, the genes coding for the five DHPA-induced enzymes have been isolated on a $7 \mathrm{kbp}$ DNA fragment and may exist as an operon. Because the expression of the enzymes encoded on a $7.0 \mathrm{kbp} B a m \mathrm{HI}$ fragment in pJF001 was constitutive in $E$. coli $5 \mathrm{~K}$ (pJF001) and inducible when the plasmid was introduced into a $K$. pneumoniae mutant defective in CHMS dehydrogenase, we deduce that an operator-promotor region was included in the $K$. pneumoniae sequence isolated (this was substantiated by showing the same pattern of expression after changing the orientation of the insert in pBR328). Apparently, another gene required for control of induced synthesis was not present in the $7 \mathrm{kbp}$ fragment. The M5a20 mutant behaved as a typical operator/repressor constitutive mutant, retaining sensitivity to catabolite repression. On the other hand, we have been unable to obtain constitutive mutants in hydroxylases, which may be because these genes are under positive control. In conclusion, a model for the regulation of enzymes of the 4-HPA pathway in $K$. pneumoniae can be proposed, similar to that described for genes encoding enzymes of the meta-cleavage pathway in Pseudomonas putida (Wigmore et al., 1977). In this model the 4-HPA hydroxylase is under positive control and 3,4-DHPA and the rest of the enzymes are under negative control.

This work was supported by a Research Grant from Vicerrectorado de Investigación, Universidad Complutense, Madrid. We thank Dr M. J. Merrick and Dr R. A. Cooper for providing the bacterial strains and J. Gibello for drawing the figures. We thank M. Zapata for correcting the English language.

\section{References}

AdACHI, K., TAKEDA, Y., SENOH, S. \& KITA, H. (1964). Metabolism of p-hydroxyphenylacetic acid in Pseudomonas ovalis. Biochimica et Biophysica Acta 93, 483-493.

Alonso, J. M. \& GARRIDo-Pertierra, A. (1982). Carboxymethylhydroxymuconic semialdehyde dehydrogenase in the 4-hydroxyphenylacetate semialdehyde catabolic pathway of Escherichia coli. Biochimica et Biophysica Acta 719, 165-167.

ANDERSON, J. J. \& DAGLEY, S. (1980). Catabolism of aromatic acids in Trichosporon cutaneum. Journal of Bacteriology 141, 534-543.

BLAKEY, E. R. (1972). Microbial conversion of $p$-hydroxyphenylacetic acid to homogentisic acid. Canadian Journal of Microbiology 18, 1247-1255.

BRADFORD, M. M. (1976). A rapid and sensitive method for the quantitation of microgram quantities of protein utilizing the principle of protein-dye binding. Analytical Biochemistry 72, 248254. 
Chow, L. T., KaHManN, R. \& KAMP, D. (1977). Electron microscopy characterization of DNA of non-effective deletion mutants of bacteriophage Mu. Journal of Molecular Biology 113, 591-609.

COOPER, R. A. \& Sxinner, M. A. (1980). Catabolism of 3- and 4hydroxyphenylacetate by the 3,4-dihydroxyphenylacetate pathway in Escherichia coli. Journal of Bacteriology 143, 302-306.

Fawcett, T., Garrido-Pertierra, A. \& COOPER, R. A. (1989). 5Carboxymethyl-2-hydroxymuconic semialdehyde dehydrogenases of Escherichia coli $\mathrm{C}$ and Klebsiella pneumoniae M5a1 show very high Nterminal sequence homology. FEMS Microbiology Letters 57, 307312.

FERRER, E. \& COOPER, R. A. (1988). Studies with a cloned Escherichia coli C 2-oxohept-3-ene-1,7-dioate hydratase gene. FEMS Microbiology Letters 52, 155-160.

Garrido-Pertierra, A. \& CoOper R. A. (1981) Identification and purification of distinct isomerase and decarboxylase enzymes involved in the 4-hydroxyphenylacetate catabolic pathway of Escherichia coli. European Journal of Biochemistry 117, 581-584.

Maniatis, T., Fritsch, E. F. \& SAmbrooK, J. (1982). Molecular Cloning: a Laboratory Manual. Cold Spring Harbor, NY: Cold Spring Harbor Laboratory.

Merrick, M. J., Gibbins, J. R. \& Postgate, J. R. (1987). A rapid and efficient method for plasmid transformation of Klebsiella pneumoniae and Escherichia coli. Journal of General Microbiology 133, 2053-2057.

MiLLER, J. H. (1972). Experiments in Molecular Genetics pp. 135-139. Cold Spring Harbor, NY: Cold Spring Harbor Laboratory.

PARKe, D. \& ORNSTON, L. N. (1976). Constitutive synthesis of enzymes of the protocatechuate pathway and of the $\beta$-ketoadipate uptake system in mutant strains of Pseudomonas putida. Journal of Bacteriology 126, 272-281.
Postma, P. W. (1986). Catabolite repression and related processes. Symposia of the Society for General Microbiology 39, 21-49.

SánChez, M., Fernández, J., Martín, M., Gibello, A. \& GarridoPertierra, A. (1989). Purification and properties of two succinic semialdehyde dehydrogenases from Klebsiella pneumoniae. Biochimica et Biophysica Acta 990, 225-231.

Sparnins, V. L. \& Chapman, P. J. (1976). Catabolism of L-tyrosine by the homoprotocatechuate pathway in Gram-positive bacteria. Journal of Bacteriology 127, 362-366.

Sparnins, V. L., Chapman, P. J. \& Dagley, S. (1974). Bacterial degradation of 4-hydroxyphenylacetic acid and homoprotocatechuic acid. Journal of Bacteriology 120, 159-167.

Sparnins, V. L., Anderson, J. J., Omans, J. \& Dagley, S. (1978). Degradation of 4-hydroxyphenylacetic acid by Trichosporon cutaneum. Journal of Bacteriology 136, 449-451.

Spoelstra, S. F. (1978). Degradation of tyrosine in anaerobically stored piggery wastes and in pig feces. Applied and Environmental Microbiology 36, 631-638.

VAN DEN TweEL, W. J. J., JANSSENs, R. J. J. \& DE BONT, J. A. M. (1986) Degradation of 4-hydroxyphenylacetate by Xanthobacter 124X; physiological resemblance with other Gram-negative bacteria. Antonie van Leeuwenhoek 52, 309-318.

VAN Den Tweel, W. J. J., SMIT, J. P. \& DE Bont, J. A. M. (1988) Catabolism of DL-1-phenylhydracrylic, phenylacetic and 3- and 4hydroxyphenylacetic acid via homogentisic acid in Flavobacterium sp. Archives of Microbiology 149, 207-213.

Wigmore, G. J., Diberardino, D. \& BAYLY, R. C. (1977). Regulation of the enzymes of the meta-cleavage pathway of Pseudomonas putida: a regulatory model. Journal of General Microbiology 100, 81-87. 